\title{
Service Quality in Nepalese Insurance Market
}

\author{
Sharda Pandey Lohani ${ }^{1}$ \\ Prof. Dr. Fatta Bahadur K.C ${ }^{2}$
}

\begin{abstract}
The present study focuses on measurement of customers' satisfaction level in Nepalese insurance market by comparing customers' perceived service quality and expectations. The questionnaire for customers' perceptions and expectations were prepared common for both life and non-life insurance companies. The data is being collected through a framed questionnaire which was totally sculpted based on the SERVQUAL model. For this study, 9 life insurance Companies, 17 non-life insurance companies, and 1 Reinsurance Company were selected for response of customers' satisfaction level.

The five dimensions of SERVQUAL are tangibility, reliability, responsiveness, assurance, and empathy. The customers perceive the service quality to be high if it is perfect on their expectation and it leads to their satisfaction with the related service. In this paper, primary data collected from the Kathmandu valley is the descriptive analysis of the life and non-life insurers in Nepalese insurance market. The study finds the gap between the expectations and perceptions of customers in Nepalese insurance market.
\end{abstract}

Key words: Service Quality, Customers' Satisfaction, Insurance Companies

\section{Introduction}

\section{Overview of Nepalese Insurance Market}

In Nepalese insurance market consists of 9 life insurance Companies, 17 non-life insurance companies, and 1 Reinsurance Company ${ }^{3}$. Besides, there are more than 0.1 million agents, around 300 surveyors, almost 5 million policyholders (Insurance Board,

1 PhD Scholar, Faculty of Management, Tribhuvan University. Email:shardaplohani@gmail.com (Corresponding Author)

2 Professor of Management, Tribhuvan University and Former Chairman, Insurance Board of Nepal.Email: fattakc@hotmail.com

3 The data was taken on 2017 May. Currently there are 18 life insurers

Lohani, S.P. \& KC, F.B. $\sim 59$ 
2016). The market is regulated by Insurance Board based on Insurance Act, 1992; Insurance Regulation, 1993 and so many Directives and Guidelines.

Table: 1 Ownership Structure of Insurance company

\begin{tabular}{lcccc}
\hline Ownership & Non-Life & Life & Reinsurance & Total \\
Government & 1 & 1 & - & 2 \\
Private & 13 & 5 & - & 18 \\
Foreign & 2 & 1 & - & 3 \\
Joint & 1 & 2 & 1 & 4 \\
\hline Total & $\mathbf{1 7}$ & $\mathbf{9}$ & $\mathbf{1}$ & $\mathbf{2 7}$ \\
\hline
\end{tabular}

Source: Economic Survey 2015/16

Currently there are 18 life insurance companies in Nepalese insurance market out of which 9 insurance companies were established in 2017. Likewise there are 21 nonlife insurance companies in Nepalese market, but still 3 non-life insurance companies have not received operating licence. There is one reinsurance company i.e. Nepal Reinsurance Company, established in 2014.

Rastriya Beema Sansthan had started to operate life business from 1972 and in the same year LIC of India ${ }^{4}$ voluntarily withdrew from the Nepalese market. In 1986, National Life and General Insurance Company Limited (Now operating life and non life business separately) was licensed as the first insurance company in the private sector with minority interest of foreign equity. It began life insurance business in 1988. In 2001, Life Insurance Corporation Nepal (LIC Nepal) was established as a joint venture company. Life insurance companies operating till June 2017 are presented in Table 2:

Table 2: Life Insurance Companies

\begin{tabular}{llllll}
\hline SN & Company & YOE & SN & Company & YOE \\
\hline 1 & Rastriya Beeam Sansthan & 1968 & 6 & Asian Life Insurance & 2008 \\
2 & National Life Insurance & 1986 & 7 & Surya Life Insurance & 2008 \\
3 & Nepal Life Insurance & 2001 & 8 & Gurans Life Insurance & 2008 \\
4 & Life Insurance Corporation (Nepal) & 2001 & 9 & Prime Life Insurance & 2008 \\
5 & Met Life ALICO & 2001 & & & \\
\hline
\end{tabular}

Source: Beema Samiti, 2017

YOE: Year of establishment

4 Indian Life insurer

$60 \sim$ Nepalese Journal of Insurance and Social Security 
Currently there are 18 life insurance companies in Nepalese insurance market. 9 insurance companies, established in 2017, have entered as new players in Nepalese insurance market but they during the study period new companies had not operated their business.

Nepal Insurance Company, nonlife insurer, was established in 1947 as the first insurance company in Nepal. Before the establishment of Nepal Insurance Company, Nepalese non life insurance requirement was met mostly by different Indian Insurance Companies. Likewise in 1968, Rastriya Beema Sansthan was established as a government insurance company for the fulfillment of national need under the Rastriya Beema sansthan act 2025 as a composite organization for both businesses i.e.; life and non life. Similarly National Life and General Insurance Company were licensed in 1986 as the Insurance Company in the private sector with partial foreign equity in composite form. In 2005, however, the non-life business of National Life and General Insurance Company was transferred to its subsidiary company - NLG Insurance Company. There are 21 nonlife insurance companies in Nepalese market, but still 3 non-life insurance companies have not received licence. The name of Non-life insurance companies and their establishment year are exhibited in Table 3.

Table 3: Non-Life Insurance Companies

\begin{tabular}{llcclc}
\hline SN & Company & YOE & SN & Company & YOE \\
\hline 1 & Nepal Insurance & 1947 & 10 & Sagarmatha Insurance & 1996 \\
2 & The Oriental Insurance & 1967 & 11 & Prabhu Insurance & 1996 \\
3 & Rastriya Beema Company & 2014 & 12 & IME General Insurance & 2000 \\
4 & National Insurance & 1973 & 13 & Prudential Insurance & 2002 \\
5 & Himalayan General Insurance & 1993 & 14 & Shikhar Insurance & 2004 \\
6 & United Insurance & 1993 & 15 & Lumbini Insurance & 2004 \\
7 & Premier Insurance & 1994 & 16 & Siddhartha Insurance & 2005 \\
8 & Everest Insurance & 1994 & 17 & NLG Insurance & 2005 \\
9 & Neco Insurance & 1996 & & & \\
\hline
\end{tabular}

Source: Beema Samiti

YOE: Year of establishment

There is a single Reinsurance Company by the name of Nepal Reinsurance Company, established in 2014 under the Companies Act, 2006. It is the successor of insurance Pool that was set up in 2003 with the aim to cover damages caused by the terrorism. It was established with the vision to provide quality reinsurance service to clients, and to be the professional reinsurer in Asia. The missions of Nepal Reinsurance Company are to become one of the esteemed re-insurer in the region and to be customer-focused and committed to growth profitability and satisfactory returns to stakeholders. 
The purpose of this study is to measure the level of satisfaction of customer of Nepalese insurance market by comparing customers' perceived service quality and expectations using the SERVQUAL model widely used by researcher and propounded by Parasuramanet. al.

\section{Literature Review}

Analyzing consumers' satisfaction and quality in service sector industries is an evolving area of research of particular importance in increasing levels of competition (Johnson, 1988). SERVQUAL is widely used today as a diagnostic tool for uncovering areas of service quality strengths and shortfalls. The practical value of SERVQUAL is twofold. First, SERVQUAL can be used as a benchmarking "best practice" can be drawn by comparing the summary SERVQUAL scores of major "players" within the same industry. Second, SERVQUAL can be used as a diagnostic or prescriptive tool. In this way, periodic measures of dimensional scores can identify problems within specific service processes. SERVQUAL's importance, particularly as a diagnostic tool, is propelling researchers to refine the measure (Lee, 1997).

The service quality is the comparison of perceived service (what customer feel about the service of Nepalese insurance market) with the expected service (what is the performance of the offered service). The customers perceive the service quality to be high if it is perfect on his expectation and it leads to their satisfaction with the related service. Service quality is a measure of how well the service level delivered matches customer expectations. Delivering quality service means conforming to customer expectations on a consistent basis(Burböck, 2014).According to Mayer (2009), when the service being delivered it is truly a pure service one requiring high customer contact frequency, having a high degree of service intangibility, and requiring service employees to work interdependently.

Quality has come to be recognized as a strategic tool for attaining operational efficiency and improved business performance. This is true for both the goods and service sectors. However, the problem with management of service quality in service firms is that quality is not easily identifiable and measurable due to inherent characteristics of services which make them different from goods (Gupta, 2016).

The importance of services to overall economies worldwide and the strategic impact of service quality perceptions, the appropriate conceptualization and measurement of the service quality construct represents an important concern for services marketers (Taylor, 1994). Improving the service quality is a key for insurance companies as it is considered a competitive advantage in the market (Burböck, 2014).

Delivering customer satisfaction is at the heart of modern marketing, which is a postpurchase judgment of the consumers. The analysis of responses clearly reveals that there exists a significant perceptual difference among customers regarding overall service quality with their respective insurance companies (Gulati, 2012).

$62 \sim$ Nepalese Journal of Insurance and Social Security 
Satisfaction is the consumers' fulfillment response. It is a judgment that a product or service feature of the product or service itself, provided (or is providing) a pleasurable level of consumption-related fulfillment, including levels of under or over fulfillment. Service quality is a measure of how well the service level delivered matches customer expectations. Delivering quality service means conforming to customer expectations on a consistent basis (Burböck, 2014).

According to Zeithaml(1988) consumers use five dimensions for evaluating service quality. The five dimensions identified by them included tangibility, reliability, responsiveness, assurance, and empathy.SERVQUAL can fruitfully be supplemented with additional qualitative or quantitative research to uncover the causes underlying the key problem area or gaps identified by a SERVQUAL study (Zeithaml,1991).SERVQUAL is a research instrument consisting of two sections: a) 22 statements designed to ascertain the general expectations of customers concerning a service and b) A matching set of 22 statements intended to measure customers' assessments of a specific firm's service quality. The five dimensions of service quality as hypothesized by Parasuraman, Zeithaml, and Berry (henceforth referred to as PZB) are tangibles, reliability, responsiveness, assurance, and empathy. According to ORWIG(1997), the definitions of these dimensions are as follow:

\begin{tabular}{|c|c|}
\hline Dimensions & Definition \\
\hline Tangibles & $\begin{array}{l}\text { Appearance of physical facilities, equipment, personnel, and } \\
\text { communication materials. }\end{array}$ \\
\hline Reliability & Ability to perform the promised service dependably and accurately. \\
\hline Responsiveness & Willingness to help customers and provide prompt service. \\
\hline Assurance & $\begin{array}{l}\text { Knowledge and courtesy of employees and their ability to convey } \\
\text { trust and confidence. }\end{array}$ \\
\hline Empathy & Caring individualized customers. \\
\hline
\end{tabular}

\section{Methodology}

According to Zeithaml(1988) consumers use five dimensions for evaluating service quality. The five dimensions identified by them included tangibility, reliability, responsiveness, assurance, and empathy. In this study,descriptive and quantitative research has been chosen. The main objective of this research work is to study to explore the gap between the perception and expectation of customers in Nepalese insurance market. The data is being collected through a framed questionnaire which was totally sculpted based on the SERVQUAL model. The questionnaire has 21 questions which were based on the RATER model (Reliability, Assurance, Tangibility, Empathy and Responsiveness model). Questions were modified after the pilot survey from 10 expert of Nepalese insurance market. Experts represent the personnel who have more than 10 years of experience in this field as executive level and researcher of insurance field. The study was conducted in the period of January 2018 to March 2018 at Kathmandu valley. Respondents were 
selected for customers' satisfaction level from the companies established before 2017. Sampling technique used for the study was judgmental sampling and 192 responses were taken from staffs, agents and customers.

SERVQUAL questionnaire (22 items) developed by Parasuramanet al. (1985) was used for the study. When designing the questionnaire some modifications and adaptations were made to selected questions to make them more relevant to the Life and NonLife Insurance Company's services at Kathmandu valley. The questionnaires consisted of 22 questions in five dimensions: tangibility, reliability, responsiveness, assurance and empathy. The questionnaire has an 'expectations' section with 21 statements and a 'perceptions' section consisting of a set of matching statements. The statements in both the expectations and perceptions sections were grouped into the five dimensions. A 5-point Likert scale was used for the scoring system with 1 representing Strongly Disagree and 5 representing Strongly Agree.

\section{Result and Discussion}

\subsection{Demographic Profile of Insurers}

There are two type of questionnaire. One for insurers which is called experts and other for customers. (Table $4 \mathrm{a}$ and $4 \mathrm{~b}$ )

\subsubsection{Profile of Experts}

The profile of experts (10) has been presented below in Table $4 \mathrm{a}$.

Table 4a: Profile of Experts

\begin{tabular}{lcc}
\hline Attribute & No & $\mathbf{\%}$ \\
\hline Types of Company & & \\
Life & 3 & 30 \\
Non Life & 6 & 60 \\
Other & 1 & 10 \\
\hline Total & $\mathbf{1 0}$ & $\mathbf{1 0 0}$ \\
\hline Position of Experts: & & \\
CEO & 7 & 70 \\
Executives & 2 & 20 \\
Researcher & 1 & 10 \\
\hline Total & $\mathbf{1 0}$ & $\mathbf{1 0 0}$ \\
\hline
\end{tabular}

\begin{tabular}{lcc}
\hline Attribute & No & $\mathbf{\%}$ \\
\hline Qualification of Experts & \\
PhD & 1 & 10 \\
CA & 2 & 20 \\
Fellowship & 1 & 10 \\
Masters & 6 & 60 \\
\hline Total & $\mathbf{1 0}$ & $\mathbf{1 0 0}$ \\
\hline
\end{tabular}

Source: Field Survey, 2017

Table $4 \mathrm{a}$ presents the profile of experts (10) where 3 experts from life insurance company, 6 experts from non-life insurance company and one researcher had given their $64 \sim$ Nepalese Journal of Insurance and Social Security 
suggestions for SEROQUEL questionnaire. In this study, experts represent their position as 7 CEOs, 2 Executives and 1 Researcher. Qualification of experts in this research study is 1 PhD holder, 2 chartered accountants, 1 Fellowship and 5 masters' degree holder.

\subsubsection{Profile of Customers}

The profile of customers (192) has been presented below in Table $4 \mathrm{~b}$.

Table 4b: Profile of Customers

\begin{tabular}{|c|c|c|c|c|c|}
\hline Attribute & No & $\%$ & Attribute & No & $\%$ \\
\hline Gender & & & Qualification & & \\
\hline Female & 50 & 25.5 & Below SLC & 10 & 5 \\
\hline Male & 142 & 74 & SLC & 21 & 11 \\
\hline Total & 192 & 100 & Intermediate & 42 & 22 \\
\hline Age & & & Bachelors & 63 & 33 \\
\hline 16 to 30 & 73 & 38 & Masters & 55 & 28.5 \\
\hline 31 to 45 & 85 & 44 & $\mathrm{PhD}$ & 1 & 0.5 \\
\hline 46 to 60 & 26 & 13.5 & Total & 192 & 100 \\
\hline above 60 & 8 & 4 & Profession & & \\
\hline Total & 192 & 100 & Government Employee & 10 & 5 \\
\hline \multicolumn{3}{|c|}{ Monthly Income (in Rs) } & Semi Government Employee & 15 & 8 \\
\hline Below 10,000 & 12 & 6 & Private Organization's Employee & 72 & 37.5 \\
\hline 10000 to 20000 & 33 & 17 & Business Person & 61 & 31.5 \\
\hline 20000 to 50000 & 74 & 39 & Retired Employee & 9 & 5 \\
\hline 50000 to 100000 & 39 & 20 & Student & 19 & 10 \\
\hline above 100000 & 22 & 12 & House makers (House wife) & 6 & 3 \\
\hline Student & 11 & 6 & Total & 192 & 100 \\
\hline
\end{tabular}

\begin{tabular}{lrr} 
Housewife & 1 & 1 \\
\hline Total & $\mathbf{1 9 2}$ & 100 \\
\hline
\end{tabular}

Source: Field Survey, 2018

Table 4b presents the profile of customers (192) where 50 customers are female and 142 are male. Monthly income of customers represents maximum 74 customers from Rs.50,000 to $1,00,000$, and minimum 14 customers represents below 10,000 and 22 customers represents maximum income group above Rs. 1,00,000 monthly income likewise there are 11 students and 1 housewife who do not have personal monthly income so they did not give information about the monthly income. Qualification of customers represents 63 customers the biggest group has bachelors' degree followed by 55 masters' degree holders' customers, 42 intermediate, 21 SLC and 10 below SLC. Profession of respondents as a customer biggest group represents the 72 private organization's employees, followed by 61 business persons, 19 students, 15 semi government employees, 10 government employees, 9 retired employees and 6 house wife. 


\subsection{Reliability Analysis}

For the measurement of internal consistency in variables, a reliability test has been done. Since the questionnaire was one of the primary concerns to this study, a study can be considered as reliable when the tool used in that study is reliable to the extent that the scores made by the respondents remain approximately the same in repeated measurement. So the measurement of Cronbach's Alpha showed in the table below the value not less than 0.60 in each measurement scale.

The reliability scale was employed to assess the validity of the five dimensions of SERVQUAL. After analyzing all the 21 questions of the structured questionnaire used in this, it has been found that $\alpha$ of the overall questionnaire is 0.942 for P(Perceptions) for E(Expectations) 0.729 (Table:3) and so the result signifies that the structured questionnaire used in this study probably indicates good reliability. Apart from analyzing the overall reliability of the questionnaire, Cronbach's $\alpha$ was also employed to measure the reliability of the underlying dimensions i.e. Tangibles, Reliability, Assurance, Responsiveness, and Empathy in Table 5.

Table 5: Item-Total Statistics (Perception P \&Expectation E)

\begin{tabular}{lcc}
\hline \multicolumn{3}{c}{ Cronbach's Alpha if Item Deleted } \\
\hline Dimensions & Perception & Expectation \\
Tangibles & 0.86 & 0.75 \\
Reliability & 0.839 & 0.67 \\
Responsiveness & 0.843 & 0.71 \\
Assurance & 0.898 & 0.72 \\
Empathy & 0.839 & 0.76 \\
\hline
\end{tabular}

Source: Field Survey 2018

\subsection{Expectations and Perceptions Analysis}

The hypothesis, H0: there is no difference between expected and perceived value on service quality of the insurance companies has been tested by the t statistics.

Service quality parameters such as: Reliability, Assurance, Tangibility, Empathy and Responsiveness as well as the SERVQUAL questionnaire that we call them service quality indicators, have been presented in Table 6 in the first column. Customer of Nepalese insurance market perception and expectation are respectively in the second, third, fourth and fifth columns with the mean value and standard deviation for each of them. Mean value for finding gap (P-E) between the perception and expectation have been evaluated in the sixth column, $t$ - value and $p$ value of $t$ statistics (5\% significance level) in seventh and eighth columns respectively calculated.

$66 \sim$ Nepalese Journal of Insurance and Social Security 


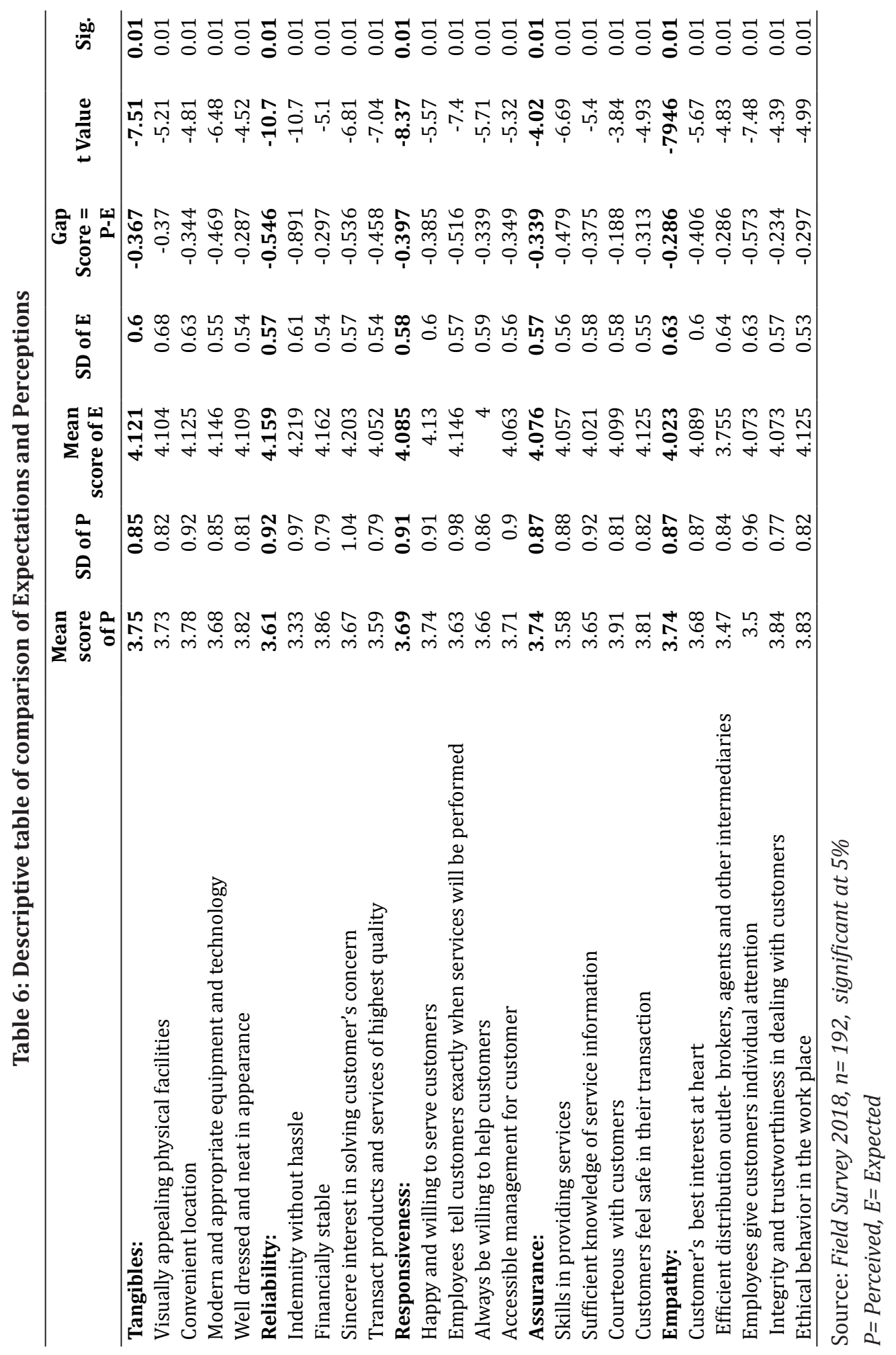

Lohani, S.P. \& KC, F.B. $\sim 67$ 
The table 6 shows that the significance value is $(0.001)$ which is less than 0.05 , so that null hypothesis is rejected for each dimensions of service quality with overall service quality. The $\mathrm{p}$ value of $\mathrm{t}$ statistics shows that there is the gap between the perceived and expected value which is significant.

This shows that there is a gap that exists between service quality dimensions of expectation and perception in services of Nepalese insurance market. The difference is more clearly exhibited by Figure 1.

Figure 1: Dimensions of Service quality in Nepalese Market

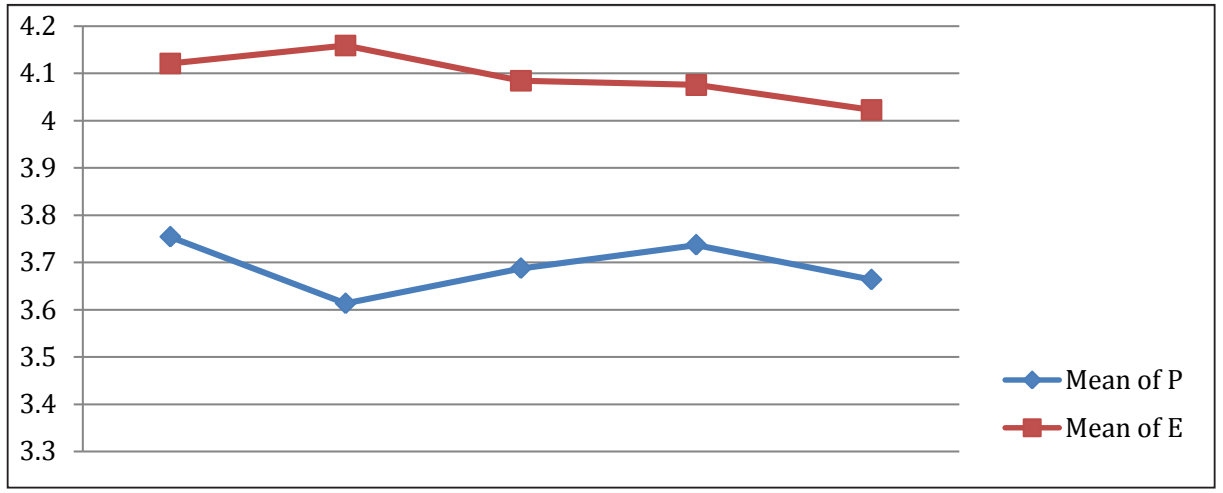

Source: Prepared by resulted primary data

Figure 1 reveals the levels of service quality in all dimensions in the customer expectations are greater than their perceptions. Therefore, the service quality offered by Nepalese insurance companies at Kathmandu valley is in weak quality through the customer perspective. On the other hand the insurance companies could not satisfy their customer expectations. It shows the bigger gap is in the reliability dimension and the small gap is in the assurance indicator of service quality. A small gap in assurance dimension shows that the customer does not feel negative from the service of employees which consists skillful job, courteous with customer etc. While a change in the dimension 'tangible' would lead to less change in satisfaction. The strategic implications are therefore straightforward: maximization of customers' satisfaction can be achieved not by maximization, but rather by optimization of the service quality (Burböck, 2014).

Firstly, the analysis revealed that most of the empathy items were regarded by customers as least important followed by assurance, responsiveness, tangibles, and reliability. This means that reliability is the most important aspect for customer's expectations. Likewise, empathy doesn't make more sense for them as compared to assurance, responsiveness, and tangibles whereas the personal relationship between the contact person and the customer is often more essential relative to other aspects of the services (Ganesh, 2000). Incorporates empathic sharing, communication of caring, evolving intimacy, and exchange more characteristic of friendship than commercial service. (Price, 1995)

$68 \sim$ Nepalese Journal of Insurance and Social Security 
Secondly, the perceptions on five dimensions of highest service quality in tangible dimension (whereas they give it to less importance -see table 4) followed by assurance, responsiveness, empathy, and reliability.

Thirdly, all the difference/gap scores were negative and statistically significant shows there is a perceived service quality gap in the Nepalese insurance market. In general, there will be negative gap between the perceptions and expectations. Only a negative asymmetric relationship between service quality and customer satisfaction can be explained by the prospect theory (Burböck, 2014).

Service organization may anticipate and even lead changes in these expectations, the customer perspective is paramount. Thus, to be service-oriented, organization need to monitor what customers want and identify where gaps exists between customer expectations and the organization delivery of services and products (Bobek, 1998).

Finally, the highest service gap between the perceptions and expectations show in reliability dimension. This means that the customer's level of confidence is low in case of indemnity, financial stability of insurance co., sincere interest in solving problems of customers by employees, and product of high quality provided by insurance company.

\section{Conclusion}

A small gap in assurance dimension shows that the customers do not feel negative about the service of employees. It indicates that employees in Nepalese insurance sector are able to show skillful job, courteous with customers etc. The skills related to the perception, processing, and the regulation of affective states of persons and others are important factors for determining how services are perceived by customers. When trying to enhance their service quality, service companies may want to focus on improving these skills. (Frese, 2008). Big Gap in reliability dimension emphasizes on the improvement in indemnity process, showing financial stability, sincere interest of employee to solving customer's concern, transact high quality of product and services. This situation indicates that there is room for improvement for reliability dimension in Nepalese insurance market. The balance theory approach might also inform training efforts. When negative relations exist between the organization and the consumer, providers might be instructed in how to assess and meet consumer expectations. And if the organizationprovider bond is negative, the enterprise may want to educate employees on the benefit of organizational membership(Carson, 1997). Finally it can be said that Nepalese insurance market should focus on planning and executing their strategies towards increasing customers' satisfaction and loyalty through improved service quality. 


\section{Reference}

Beema Samit. (2014). Strategic Plan 2014-2019. Insurance Regulatory Authority of Nepal. Insurance Regulatory Authority of Nepal.

Beema Samiti . (2071/72). Annual Report . Kupandol, Lalitpur: Beema Samiti.

Bobek S., M. L., L. \& R. S., L. (1998). Service Orientation in Transitional Economies: Analysis of Critical Service Factors in two. Journal of East European Management Studies, Vol. 3, No. 4 (1998), pp. 319-338. Rainer Hampp Verlag.

Burböck, B. (2014). Prospect Theory and servqual. NonCommercial-NoDerivatives 4.0 International. License (http://creativecommons.org/licenses/by-nc-nd/4.0/).

Carson, P. \& Phillips, K. D. (1997). Balance Theory Applied to Service Quality: A Focus on the Organization, Provider, and. Journal of Business and Psychology, Vol. 12, No. 2 (Dec., 1997), pp. 99-120. Springer.

David, M. \& Mayer, M. G. (2009). Service Attribute Boundary Conditions of the Service Climate-Customer Satisfaction Link. The Academy of Management Journal, Vol. 52, No. 5 (Oct., 2009), pp. 1034-1050. Academy of Management.

Eugene W. \& Anderson, C. F. (1994). Customer Satisfaction, Market Share, and Profitability: Findings from Sweden. Journal of Marketing, Vol. 58, No. 3 (Jul., 1994), pp. 53-66. American Marketing Association.

Frese, A. G. (2008). Linking Service Employees' Emotional Competence to Customer Satisfaction: A Multilevel. Journal of Organizational Behavior, Vol. 29, No. 2, Contexts of Positive Organizational Behavior (Feb., 2008), pp. 155-170. Wiley.

Government of Nepal Ministry of Finance . (2016). Economic Survey. Singhadurbar, Kathmandu: Government of Nepal Ministry of Finance.

Gulati , A. K. (2012). E-CRM and Customer Satisfaction in Indian Insurance Industry. Asian Journal of Business and Economics. Asian Journal of Business and Economics.

Gupta, S. K. ( 2016, 15 August). Measuring Service Quality:SERVQUAL vs. SERVPERF Scales. ResearchGate. https://www.researchgate.net/publication/228778534.

Ganesh, M. J. (2000). Understanding the Customer Base of Service Providers: An Examination of the Differences. Journal of Marketing, Vol. 64, No. 3 (Jul., 2000), pp. 65-87. American Marketing Association.

Lee, W. J. (1997). Pragmatic Perspectives on the Measurement of Information Systems Service Quality. MIS Quarterly, Vol. 21, No. 2 (Jun., 1997), pp. 223-240. Management Information Systems Research Center, University of Minnesota.

Linda L. \& Johnson, M. J. (1988). Service Quality Determinants and Effectiveness in the Real Estate Brokerage Industry. The Journal of Real Estate Research, Vol. 3, No. 2 (Summer 1988), pp. 21-36. American Real Estate Society.

$70 \sim$ Nepalese Journal of Insurance and Social Security 
Linda L . \& Price, E. J. (1995). Going to Extremes: Managing Service Encounters and Assessing Provider Performance. Journal of Marketing, Vol. 59, No. 2 (Apr., 1995), pp. 83-97. American Marketing Association.

Robert, A. \& Orwing, J. P. (1997). An Empirical Investigation into the validity of SERVQUAL in thePublic Sector. Public Administration Quarterly, Vol. 21, No. 1 (SPRING, 1997), pp. 54-68. SPAEF.

Steven A. \& Taylor, J. J. (1994). An Empirical Assessment of the SERVPERF Scale. Journal of Marketing Theory and Practice, Vol. 2, No. 4 (Fall, 1994), pp. 52-69. Taylor \& Francis, Ltd.

Taylor, S. (1994). Waiting for Service: The Relationship between Delays and Evaluations of Service. Journal of Marketing, Vol. 58, No. 2 (Apr., 1994), pp. 56-69. American Marketing Association.

Tripp, C. (1997). Services Advertising: An Overview and Summary of Research, 19801995. Journal of Advertising, Vol. 26, No. 4, Services Advertising (Winter, 1997), pp. 21-. Taylor \& Francis, Ltd.

Valarie, A. \& Zeithaml, L. L. (1988). Communication and Control Processes in the Delivery of Service Quality. Journal of Marketing, Vol. 52, No. 2 (Apr., 1988), pp. 35-48. American Marketing Association. . (1988). Communication and Control Processes in the Delivery of Service Quality. Journal of Marketing, Vol. 52, No. 2 (Apr., 1988), pp. 35-48, 15. American Marketing Association.

- (1991). Refinement and Reassessment of the SERVQUAL SCALE. Journal of Retailing. 67(4):420-450. 